\title{
Systemic treatment in advanced soft tissue sarcoma: what is standard, what is new
}

\author{
Anna Maria Frezza ${ }^{1}$, Silvia Stacchiotti ${ }^{1}$ and Alessandro Gronchi ${ }^{2^{*}}$ (D)
}

\begin{abstract}
For metastatic soft tissue sarcoma (STS) patients not eligible for surgery, systemic treatments, including standard chemotherapy and newer biological compounds, still play the most relevant role in the management of the disease. An anthracycline and alkylating agent combination has formed the cornerstone of chemotherapy in STS for more than 30 years, with its value over that of administration of anthracycline as a single agent still being debated. Efforts have been made to improve the activity and minimise the toxicity of the combination, as well as to explore the upfront efficacy of agents known to be active in sarcoma and to develop new biological compounds. Nevertheless, beyond the first line, evidence for medical treatment in STS is less robust and all the more driven by histology. Thus, the introduction of kinases and small molecule inhibitors in the treatment armamentarium for STS is a major achievement in this setting. Preliminary data on immunotherapy are also available and discussed in this review.
\end{abstract}

Keywords: Sarcoma, Advanced sarcoma, Metastatic sarcoma, Chemotherapy, Tyrosine kinase inhibitors, VEGF inhibitors, Immunotherapy, Survival

\section{Background}

Soft tissue sarcomas (STS) are a heterogeneous group of rare neoplasms with mesenchymal origin, encompassing approximately 70 different entities [1]. The natural history of these aggressive diseases is characterised by a strong tendency toward local recurrence and metastatic spreading, which occur in $10-30 \%$ and $30-40 \%$ of patients, respectively, despite optimal initial strategies. The lung is the most common site of STS metastases and pulmonary metastasectomy is the standard treatment for selected patients with limited lung disease. For metastatic patients not eligible for surgery, chemotherapy still plays the most relevant role in the management of the disease. Despite advances over the last decades, the outcome for metastatic patients remains poor, with a median reported overall survival (OS) of 14-17 months [2-4]. In this review, we aim to summarise the results from the most recent studies on metastatic STS and provide indications on the treatment of this rare condition.

\footnotetext{
* Correspondence: alessandro.gronchi@istitutotumori.mi.it

${ }^{2}$ Department of Surgery, Fondazione IRCCS Istituto Nazionale dei Tumori, Via Venezian 1, Milan 20133, Italy

Full list of author information is available at the end of the article
}

\section{First-line treatment in STS Cytotoxic agents}

Doxorubicin and ifosfamide have been used in STS for more than 30 years and remain the cornerstone for the treatment of metastatic disease. Nevertheless, whether doxorubicin alone or the combination of doxorubicin and ifosfamide should be used routinely remains debatable. The results from a large, prospective, randomised trial [2], which compared full-dose doxorubicin-ifosfamide versus doxorubicin alone in patients with advanced STS of all types showed no significant difference in OS between groups (14.3 vs. 12.8 months, respectively, $P=0.076$ ). Conversely, a significant advantage in both progression free survival (PFS; 7.4 vs. 4.6 months, $P=0.003$ ) and overall response rate (ORR; $26 \%$ vs. $14 \%, P<0.0006)$ was highlighted in the group treated with doxorubicin and ifosfamide. Therefore, it could be reasonable to advocate the use of the combination in fit patients, when disease shrinkage is desirable in order to achieve surgical resection or improve symptom control. Nevertheless, the pooling of several histologies, particularly at a time when different agents have been proven to exert selective activity in specific subtypes, represents a strong limitation in the study [2]. Histology should be considered during decision-making, extending the use of the combination to 
those subtypes that could benefit more from ifosfamide addition (i.e. synovial sarcoma). Conversely, according to the available retrospective data [5], the activity of ifosfamide is limited in leiomyosarcoma; in this subtype, the combination of doxorubicin and dacarbazine is a potential multi-agent first-line treatment option. Given the key role of doxorubicin in the treatment of STS, several types of anthracycline have been recently tested in first-line treatment, with the view of improving the outcome in patients with advanced disease.

Aldoxorubicin is a novel prodrug of doxorubicin, characterised by a $\mathrm{pH}$-sensitive linker that mediates the binding with endogenous albumin in the bloodstream. The albumin-drug conjugate preferentially localises in the acidic tumour environment where doxorubicin is released, potentially enhancing drug activity and minimising toxicity. In a phase $2 \mathrm{~b}$ study randomising 123 advanced STS patients to receive doxorubicin or aldoxorubicin [6], the prodrug showed superior efficacy by prolonging PFS (5.6 vs. 2.7 months; $P=0.02)$ and improving ORR $(25 \%$ vs. $0 \%)$. A first-line phase Ib study is currently on-going to evaluate the safety and activity of aldoxorubicin in association with ifosfamide (NCT02235701).

Amrubicin, a third generation anthracycline, has been suggested to be less toxic than doxorubicin, with an ex vivo study proving a lower accumulation in human myocardial strips and a lower tendency to cause cellular oxidative damage $[7,8]$. A phase II study with single-agent amrubicin in 24 chemotherapy-naïve STS patients showed a ORR (13\%) and a PFS (5.8 months) similar to frontline doxorubicin, with proven tolerability up to a higher cumulative dose [9]. However, a randomised, controlled study assessing non-inferiority of amrubicin compared to the standard is still lacking. Interestingly, a remarkably durable response in a patient with a TLSCHOP translocated myxoid liposarcoma was noticed [9].

Similarly to that reported with aldoxorubicin and amrubicin alone, attempts to identify newer DNAalkylators to maximise the efficacy of the combination has not yet led to substantial progress. Palifosfamide, the active metabolite of ifosfamide, does not require prodrug activation and avoids the generation of toxic metabolites. Its efficacy was explored in the PICASSO III study [3], which randomised 447 previously untreated STS patients to receive doxorubicin and palifosfamide or doxorubicin and placebo. Unfortunately, this phase 3 study was unable to confirm the encouraging results of the previous phase 2 trial [10], failing to show any improvement in PFS for the experimental arm (6.0 vs. 5.2 months; $P=0.19)$. Likewise, the phase 3 study from SARC exploring the value of adding evofosfamide, a prodrug preferentially activated under hypoxic conditions, to doxorubicin, did not show any advantage in OS (18.4 vs. 19.0 months; $\mathrm{HR}=1.06)$ and PFS (6.3 vs. 6.0 months; $\mathrm{HR}=0.85)$ for the combination compared to single agent doxorubicin [11].

By adopting the experience developed in refractory STS, the upfront administration of compounds known to be active in further lines has also been explored. Although taxanes are inactive in most subtypes, the combination of gemcitabine and docetaxel (GD) has shown activity in STS, probably due to a synergistic action between the two drugs, and is used in relapsed STS after failure of at least one line of chemotherapy. With the aim of assessing the value of GD as a first-line treatment, a comparative phase 3 study (GEDDIS trial) was run [12], randomising 257 advanced STS patients to receive upfront doxorubicin or GD. The study confirmed the superiority of single agent doxorubicin in terms ORR $(65.9 \%$ vs. $58.6 \%)$ and tolerability, with similar PFS (23 vs. 24 weeks).

Trabectedin, a tetrahydroisoquinoline alkaloid currently approved both in Europe and USA for the treatment of advanced, refractory STS, also failed to show superiority as first-line treatment over doxorubicin in two phase 2 studies $[13,14]$. The phase $2 \mathrm{~b}$ TRUSTS trial, comparing doxorubicin with trabectedin single agent administered over two different schedules (3- and 24-h infusion), was terminated due to lack of superiority in both trabectedin treatment arms as compared to the control arm [13]. Likewise, a phase 2 study from the Spanish Sarcoma Group comparing doxorubicin single agent with the combination of doxorubicin and trabectedin was stopped for futility after the interim analysis (median PFS was 5.5 and 5.7 months in the control and experimental arm, respectively) [14].

Similar results have been reported in a first-line phase 2 study comparing brostallicin, a DNA minor-groove binder, with doxorubicin [15]. Despite being well-tolerated, brostallicin was inferior to doxorubicin both for survival (1-year PFS; $6.5 \%$ vs. $15.6 \%$; 1 -year OS $50.5 \%$ vs. $57.9 \%$ ) and objective response rate (RR; $3.9 \%$ vs. $22.2 \%$ ).

The results from the studies above underline how, despite efforts over the last years, no regimens have succeeded in providing convincing evidence of superiority as upfront treatment compared to doxorubicin, which remains the standard of care, with or without the association with ifosfamide.

\section{Monoclonal antibodies}

A possible breakthrough in the first-line setting is represented by the recently published results of an open-label phase $1 \mathrm{~b} / 2$ trial comparing olaratumab and doxorubicin versus doxorubicin alone for treatment of chemotherapynaïve STS patients [4]. Olaratumab is a recombinant human monoclonal antibody that specifically targets PDGFR $\alpha$, blocking PDGF-AA, PDGF-BB and PDGF-CC binding and receptor activation. Preclinical data suggest 
how olaratumab, alone or in combination with doxorubicin, might exert anti-tumour activity in human sarcoma xenograft models [16]. The results of the phase $1 \mathrm{~b} / 2$ study, randomising 133 patients to receive olaratumab plus doxorubicin or doxorubicin alone, showed a median PFS of 6.6 (95\% CI, 4.1-8.3) and 4.1 months (2.8-5.4), a median OS of 26.5 (20.9-31.7) and 14.7 months (9.217.1), and an objective RR of $18.2 \%$ (9.8-29.6) and $11.9 \%$ (5.3-22.2), respectively [4]. The addition of olaratumab to doxorubicin resulted, for the first time, in a clear advantage in OS. The drug has been granted 'accelerated approval' status by the Food and Drugs Administration and it has been recommended by the European Medicines Agency for conditional approval. However, the large disparity between OS (11.8 months) and PFS benefit (2.5 months) raised important questions on the drug's mechanisms of action and the reliability of results. The discrepancy may be partially attributed to differences in treatment duration independent of radiological progression, imbalances in histological subtypes, subsequent therapies, and death due to unrelated events. A confirmatory phase 3 study, the ANNOUNCE (NCT02451943), was run and is fully enrolled, with results awaited in the next months. Additionally, a phase 1b study (NCT02783599) is on-going to evaluate the modulation of biological markers in STS patients receiving olaratumab and doxorubicin, with the aim of gaining a better insight on olaratumab's mechanism of action.

The prospective evidence for first-line systemic treatment in STS is summarised in Table 1.

\section{Tyrosine-kinase inhibitors}

Dermatofibrosarcoma protuberans (DFSP) is marked by a translocation resulting in the COL1A1/PDGFB fusion gene, responsible for platelet derived growth factor betareceptor (PDGFRB) activation [17, 18]. This rare STS subtype is characterised by a high tendency toward local aggressiveness and low metastatic potential, which is predominantly associated to the presence of a more aggressive, fibrosarcomatous (FS) component. Imatinib mesylate is highly active in this histology (ORR, 60-70\%), it is currently approved and recommended as upfront treatment. FS-DFSP maintains the translocation and is sensitive to imatinib, and should be therefore considered as a first-line option. The RR in patients with FS-DFSP on imatinib is high (approximately 80\%), but responses tend to be shorter compared to the classic subtype [19, 20]. Alveolar soft part sarcoma (ASPS) and solitary fibrous tumour (SFT), especially the malignant variant lacking a dedifferentiated component, show limited sensitivity to standard chemotherapy [21, 22]. Angiogenesis has been shown to play a crucial role in the pathogenesis of these subtypes, and encouraging results have been reported with sunitinib and pazopanib in pre-treated patients. Based on the above, there is a rationale to believe that both ASPS and SFT may benefit from the upfront use of antiangiogenic tyrosine kinase inhibitors (TKIs). A prospective phase 2 study exploring pazopanib activity in first-line treatment of SFT is ongoing (NCT02066285).

\section{Second and further lines in STS Cytotoxic agents}

The evidence for treatment of metastatic STS after the first line is predominantly built on phase 2 studies suggesting a selective activity of different agents in specific sarcoma subtypes. Gemcitabine is active in refractory STS, more convincing in leiomyosarcoma, angiosarcoma and, to some extent, pleomorphic sarcoma [23]. Conflicting evidence are available on the advantage of a GD regimen over gemcitabine alone, whose better tolerability makes it more appealing in a palliative setting [24, 25]. The activity of gemcitabine in combination with vinorelbine or dacarbazine has also been explored. In a phase II study including adult STS of all types, the combination of gemcitabine and vinorelbine resulted in a clinical benefit rate of 25\% [26]; one complete radiological response lasting more than 1 year in a patient with high-grade pleomorphic spindle-cell sarcoma was also reported. In the same population, gemcitabine and dacarbazine compared favourably with dacarbazine single agent in terms of median PFS (4.2 vs. 2 months, $P=0.005)$, OS (16.8 vs. 8.2 months, $P=0.014)$ and clinical benefit rate (49\% vs. $25 \%$, $P=0.009)$ [27]. Paclitaxel alone is active in angiosarcoma. Preclinical data suggest that $\beta$-blockade induces apoptosis in malignant vascular tumour cells and results in a significant reduction of angiosarcoma growth in in vivo tumour models [28]. Propanolol, alone or in combination with metronomic chemotherapy, has been reported to induce responses in advanced pretreated angiosarcoma patients $[29,30]$. Synovial sarcoma is particularly sensitive to ifosfamide [31-33]. As previously mentioned, trabectedin is currently approved in Europe, USA and Japan for the treatment of advanced STS refractory to anthracycline. Leiomyosarcoma, liposarcoma and synovial sarcoma have a higher sensitivity to trabectedin compared to other STS subtypes [34, 35]. Among liposarcomas, an extremely heterogeneous family of STS, myxoid liposarcoma is known to be marked by the $t(12 ; 16)(q 13 ; p 11)$, detected in more than $90 \%$ of cases. In this subtype, the drug has been proven to exert an additional 'targeted' mechanism of action, promoting tumour differentiation through the inactivation of the FUS-CHOP oncogene [36]. This accounts for an activity of the drug in myxoid liposarcoma significantly above the average shown is the other STS subtypes [37]. Similarly to trabectedin, eribulin mesylate is a synthetic analogue of halichondrin $\mathrm{B}$, belonging to the family of microtubule-targeting agents. In addition to its cytotoxic effect, eribulin has been shown to promote vascular 
Table 1 First-line treatment in soft tissue sarcomas: prospective evidence

\begin{tabular}{|c|c|c|c|c|c|c|}
\hline Study & $\begin{array}{l}\text { Study } \\
\text { phase }\end{array}$ & Drug and schedule & Patients & $\begin{array}{l}\text { Overall response } \\
\text { rate }(\%)\end{array}$ & $\begin{array}{l}\text { Progression-free } \\
\text { survival (months) }\end{array}$ & $\begin{array}{l}\text { Overall survival } \\
\text { (months) }\end{array}$ \\
\hline \multicolumn{7}{|l|}{ Cytotoxic agents } \\
\hline Judson et al., 2014 [2] & III & $\begin{array}{l}\text { Arm A: D }\left(75 \mathrm{mg} / \mathrm{m}^{2}\right) \text { 3-weekly } \\
\text { Arm B: D }\left(25 \mathrm{mg} / \mathrm{m}^{2} / \text { day, days } 1-3\right)+ \\
\text { I (10 g/m² over } 4 \text { days }) 3 \text {-weekly }\end{array}$ & $\begin{array}{l}\text { Arm A: } 228 \\
\text { Arm B: } 227\end{array}$ & $\begin{array}{l}\text { Arm A: } 14 \\
\text { Arm B: } 26\end{array}$ & $\begin{array}{l}\text { Arm A: } 4.6 \\
\text { Arm B: } 7.4\end{array}$ & $\begin{array}{l}\text { Arm A: } 12.8 \\
\text { Arm B: } 14.3\end{array}$ \\
\hline Chawla et al., 2015 [6] & $\| \mathrm{llb}$ & $\begin{array}{l}\text { Arm A: D }\left(75 \mathrm{mg} / \mathrm{m}^{2}\right) \text { 3-weekly } \\
\text { Arm B: Aldoxorubicin }\left(350 \mathrm{mg} / \mathrm{m}^{2}\right) \\
\text { 3-weekly }\end{array}$ & $\begin{array}{l}\text { Arm A: } 40 \\
\text { Arm B: } 83\end{array}$ & $\begin{array}{l}\text { Arm A: } 0 \\
\text { Arm B: } 25\end{array}$ & $\begin{array}{l}\text { Arm A: } 2.7 \\
\text { Arm B: } 5.6\end{array}$ & $\begin{array}{l}\text { Arm A: } 14.3 \\
\text { Arm B: } 15.8\end{array}$ \\
\hline Gupta et al., 2016 [9] & $\|$ & $\begin{array}{l}\text { Amrubicin } 40 \mathrm{mg} / \mathrm{m}^{2} / \text { day, days } 1-3 \text {, } \\
3 \text { weekly }\end{array}$ & 24 & 13 & 5.8 & 26 \\
\hline Ryan et al., 2016 [3] & III & $\begin{array}{l}\text { Arm A: D }\left(75 \mathrm{mg} / \mathrm{m}^{2}\right)+ \\
\text { P (150 mg/m²/day, days 1-3) } \\
\text { 3-weekly } \\
\text { Arm B: D }\left(75 \mathrm{mg} / \mathrm{m}^{2}\right)+\text { placebo, } \\
\text { 3-weekly }\end{array}$ & $\begin{array}{l}\text { Arm A: } 227 \\
\text { Arm B: } 221\end{array}$ & $\begin{array}{l}\text { Arm A: } 28.3 \\
\text { Arm B: } 19.9\end{array}$ & $\begin{array}{l}\text { Arm A: } 6 \\
\text { Arm B: } 5.2\end{array}$ & $\begin{array}{l}\text { Arm A: } 15.9 \\
\text { Arm B: } 16.9\end{array}$ \\
\hline Tap et al., 2016 [4] & III & $\begin{array}{l}\text { Arm A: Evofosfamide }\left(300 \mathrm{mg} / \mathrm{m}^{2}\right)+ \\
\text { D }\left(75 \mathrm{mg} / \mathrm{m}^{2}\right), 3 \text {-weekly } \\
\text { Arm B: D }\left(75 \mathrm{mg} / \mathrm{m}^{2}\right) \text { 3-weekly }\end{array}$ & $\begin{array}{l}\text { Arm A: } 317 \\
\text { Arm B: } 323\end{array}$ & $\begin{array}{l}\text { Arm A: } 28.4 \\
\text { Arm B: } 18.3\end{array}$ & $\begin{array}{l}\text { Arm A: } 6.3 \\
\text { Arm B: } 6\end{array}$ & $\begin{array}{l}\text { Arm A: } 18.4 \\
\text { Arm B: } 19\end{array}$ \\
\hline Seddon et al., 2015 [12] & III & $\begin{array}{l}\text { Arm A: G }\left(625 \mathrm{mg} / \mathrm{m}^{2} \text { day } 1 \text { and } 8\right)+ \\
\text { Doc }\left(75 \mathrm{mg} / \mathrm{m}^{2} \text { day 8), 3-weekly }\right. \\
\text { Arm B: D }\left(75 \mathrm{mg} / \mathrm{m}^{2}\right) \text {, 3-weekly }\end{array}$ & $\begin{array}{l}\text { Arm A: } 128 \\
\text { Arm B: } 129\end{array}$ & $\begin{array}{l}\text { Arm A: } 58.6 \\
\text { Arm B: } 65.9\end{array}$ & $\begin{array}{l}\text { Arm A: } 5.6 \\
\text { Arm B: } 5.3\end{array}$ & $\begin{array}{l}\text { Arm A: } 14.7 \\
\text { Arm B: } 16.5\end{array}$ \\
\hline Bui-Nguyen et al., 2015 [13] & $\| \mathrm{b}$ & $\begin{array}{l}\text { Arm A: T }\left(1.3 \mathrm{mg} / \mathrm{m}^{2}\right) \text { 3-hour infusion, } \\
\text { 3-weekly } \\
\text { Arm B: T }\left(1.5 \mathrm{mg} / \mathrm{m}^{2}\right) \text { 24-hour infusion, } \\
\text { 3-weekly } \\
\text { Arm C: D }\left(75 \mathrm{mg} / \mathrm{m}^{2}\right) \text { 3-weekly }\end{array}$ & $\begin{array}{l}\text { Arm A: } 47 \\
\text { Arm B: } 43 \\
\text { Arm C: } 43\end{array}$ & $\begin{array}{l}\text { Arm A: } 14.8 \\
\text { Arm B: } 4.7 \\
\text { Arm C: } 25.6\end{array}$ & $\begin{array}{l}\text { Arm A: } 2.8 \\
\text { Arm B: } 3.1 \\
\text { Arm C: } 5.5\end{array}$ & NA \\
\hline Martin-Broto et al., 2016 [14] & $\|$ & $\begin{array}{l}\text { Arm A: T }\left(1.1 \mathrm{mg} / \mathrm{m}^{2}\right) \text { 3-hours infusion + } \\
\text { D }\left(60 \mathrm{mg} / \mathrm{m}^{2}\right), 3-\text { weekly } \\
\text { Arm B: D }\left(75 \mathrm{mg} / \mathrm{m}^{2}\right) \text {, 3-weekly }\end{array}$ & $\begin{array}{l}\text { Arm A: } 54 \\
\text { Arm B: } 59\end{array}$ & $\begin{array}{l}\text { Arm A: } 17 \\
\text { Arm B: } 17\end{array}$ & $\begin{array}{l}\text { Arm A: } 5.7 \\
\text { Arm B: } 5.5\end{array}$ & $\begin{array}{l}\text { Arm A: } 13.3 \\
\text { Arm B: } 13.7\end{array}$ \\
\hline Gelderblom et al., 2014 [15] & $\|$ & $\begin{array}{l}\text { Arm A: Brostallicin }\left(10 \mathrm{mg} / \mathrm{m}^{2}\right) \text {, 3-weekly } \\
\text { Arm B: D }\left(75 \mathrm{mg} / \mathrm{m}^{2}\right) \text {, 3-weekly }\end{array}$ & $\begin{array}{l}\text { Arm A: } 79 \\
\text { Arm B: } 39\end{array}$ & $\begin{array}{l}\text { Arm A: } 3.9 \\
\text { Arm B: } 22\end{array}$ & $\begin{array}{l}\text { Arm A: } 1.6 \\
\text { Arm B: } 6\end{array}$ & NA \\
\hline \multicolumn{7}{|l|}{ Biological agents } \\
\hline Tap et al., 2016 [11] & Ib/l| & $\begin{array}{l}\text { Arm A: Olaratumab }(15 \mathrm{mg} / \mathrm{kg}) \text { day } 1 \\
\text { and } 8+\mathrm{D}\left(75 \mathrm{mg} / \mathrm{m}^{2}\right) ; 3 \text {-weekly } \\
\text { Arm B: D }\left(75 \mathrm{mg} / \mathrm{m}^{2}\right) \text {, 3-weekly }\end{array}$ & $\begin{array}{l}\text { Arm A: } 66 \\
\text { Arm B: } 67\end{array}$ & $\begin{array}{l}\text { Arm A: } 18.2 \\
\text { Arm B: } 11.9\end{array}$ & $\begin{array}{l}\text { Arm A: } 6.6 \\
\text { Arm B: } 4.1\end{array}$ & $\begin{array}{l}\text { Arm A: } 26.5 \\
\text { Arm B: } 14.7\end{array}$ \\
\hline
\end{tabular}

$D$ doxorubicine; $I$ ifosfamide; $P$ palifosfamide; $G$ gemcitabine; Doc docetaxel; $T$ trabectedin; $N A$ not available

remodelling and reversal of the epithelial-mesenchymal transition [38, 39]. A phase 3 trial comparing eribulin with an active control, dacarbazine, in patients with advanced leiomyosarcoma and liposarcoma reported and improvement in OS for patients receiving eribulin (13.5 vs. 11.5 months, respectively; $P=0.0169$ ), with the greatest benefit observed in patients with liposarcoma (median OS, 15.6 vs. 8.4) [40]; median PFS was similar in both treatment groups (2.6 months). The positive effect on OS compared with absence of impact on PFS might be partially explained by the biological effects of the drug on vascularisation and microenvironment, which could potentially enhance response to subsequent treatments. In 2016, the Food and Drugs Administration approved eribulin for the treatment of patients with advanced liposarcoma progressing on anthracycline. A phase 3 study evaluating aldoxorubicin compared to investigator's choice in 433 patients with relapsed or refractory STS (NCT02049905) failed to demonstrate a significant improvement in PFS over the entire study population (full data are expected soon). However, preliminary results suggest a significant prolongation favouring aldoxorubicin for leiomyosarcoma and liposarcoma; final results are awaited in the upcoming months.

Aside from the introduction of new drugs such as eribulin, the tendency toward medical treatment being increasingly driven by histology is considered a major determinant in the OS improvement of advanced STS [41-43]. The selective activity of cytotoxic agents and newer compounds across STS histologies is summarised in Table 2.

\section{Kinase inhibitors}

One of the most encouraging fields of development in STS over the last years has been that of the introduction of kinase-inhibitors in the treatment armamentarium, as exemplified by imatinib for the treatment of gastrointestinal 
Table 2 Histology-driven approach in soft tissue sarcomas

\begin{tabular}{lll}
\hline Histology & Cytotoxic compounds with selective activity & Target-therapies with selective activities \\
\hline Leiomyosarcoma & Gemcitabine \pm docetaxel, trabectedin, dacarbazine & Pazopanib \\
Dedifferentiated liposarcoma & High-dose ifosfamide, trabectedin, eribulin & \\
Myxoid liposarcoma & Trabectedin, eribulin & Pazopanib \\
Synovial sarcoma & Ifosfamide, trabectedin & Pazopanib \\
Epithelioid sarcoma & Gemcitabine & Pazopanib, sorafenib \\
Angiosarcoma/intimal sarcoma & Gemcitabine, paclitaxel & Pazopanib, sunitinib, cedinarib \\
Alveolar soft part sarcoma & & Pazopanib, sunitinib \\
Solitary fibrous tumour & Dacarbazine & Pazopanib, sunitinib \\
Clear cell sarcoma & & Pazopanib, sunitinib \\
Extraskeletal myxoid chondrosarcoma & & m-TOR inhibitors \\
Perivascular epithelioid cell tumor & Gemcitabine & Pazopanib, m-TOR inhibitors, interferon \\
Epithelioid hemangioendothelioma & & Crizotinib \\
Inflammatory myofibroblastic tumour & & \\
Undifferentiated pleomorphic sarcoma & High-dose ifosfamide, gemcitabine & Imatinib, sorafenib, sunitinib \\
Dermatofibrosarcoma protuberans & &
\end{tabular}

stromal tumours [44]. Prospective evidence for kinase inhibitors in STS is summarised in Table 3.

\section{Tyrosine kinase inhibitors (TKIs) targeting angiogenesis}

A variety of TKIs exert their antitumor effect by targeting angiogenesis. Pazopanib, a TKI targeting VEGFR 13, PDGFRA, PDGFRB and KIT, was tested in advanced, pre-treated STS patients, and showed an improvement in PFS of 3 months compared to placebo [45]; a good performance status and a low or intermediate tumour grade were selected as favourable prognostic factors. Liposarcomas were excluded from the study based on the negative results reported in a previous phase 2 study for this histology [46]. The results of the PALETTE study [45] led to pazopanib approval in advanced, refractory non-lipomatous sarcoma. Although the mechanism of action is still poorly understood, pazopanib seems to be more active in leiomyosarcoma, synovial sarcoma, vascular sarcomas (epithelioid hemangioendothelioma and intimal sarcoma), ASPS and SFT [45, 47-49]. Further studies are ongoing to better exploit its activity across STS histologies and evaluate the combination of pazopanib with cytotoxic (i.e. gemcitabine, taxanes) and newer (i.e. anti-endoglin, m-TOR inhibitors) agents [50-53]. Regorafenib, a TKI targeting VEGFR1-3, RET, KIT, PDGFR and Raf, was found to be associated with a minor PFS advantage in non-adipocytic STS progressing on anthracycline in a single phase II study [54].

In addition to pazopanib and regorafenib, several other TKIs targeting angiogenesis have been tested in sarcoma, showing a different activity across histologies. Angiosarcoma and SFT seem sensitive to sorafenib [55]. The antitumour activity of sunitinib was shown in ASPS, SFT, clear cell sarcoma and extraskeletal myxoid chondrosarcoma [48, 56-60]; no signs of activity were found in most of the remaining STS subtypes. Encouraging results were reported with cediranib, a potent inhibitor of VEGFR1, VEGFR3 and KIT, in ASPS [61]; in the same subtype, limited evidence is also available for anlotinib [62]. Tivozanib, a TKI targeting VEGFR1-3, PDGFR $\alpha / \beta$ and cKIT, showed signs of activity in a phase 2 study including 58 heavily pre-treated STS patients (47\% leiomyosarcoma) [63]. Responses to sorafenib and sunitinib have been reported in advanced DFSP progressing on imatinib, and a phase 2 study with pazopanib has been recently completed (NCT01059656) [64, 65].

\section{Other TKIs}

The intracellular tyrosine kinase c-SRC pathway, including as downstream targets EGFR, PDGFR and c-KIT, has been reported to be up-regulated in STS, especially leiomyosarcoma and synovial sarcoma. Despite encouraging preclinical data, negative results have been reported in two phase 2 studies exploring the activity of dasatinib, a potent small molecule inhibitor of SRC, in advanced, pre-treated STS patients [66, 67]. Additionally, the hepatocyte growth factor receptor (MET) and anaplastic lymphoma kinase (ALK) are TK-receptors, whose disruption promotes cellular proliferation, angiogenesis and disease spreading in many solid cancers, including STS. Crizotinib, a TKI targeting both ALK and MET, has shown activity in ALK-rearranged inflammatory miofibroblastic tumours (IMTs), which account for approximately $50 \%$ of all IMT cases. The EORTC phase 2 study, CREATE, is currently exploring crizotinib activity in IMT, alveolar rhabdomyosarcoma, clear cell sarcoma and ASPS 


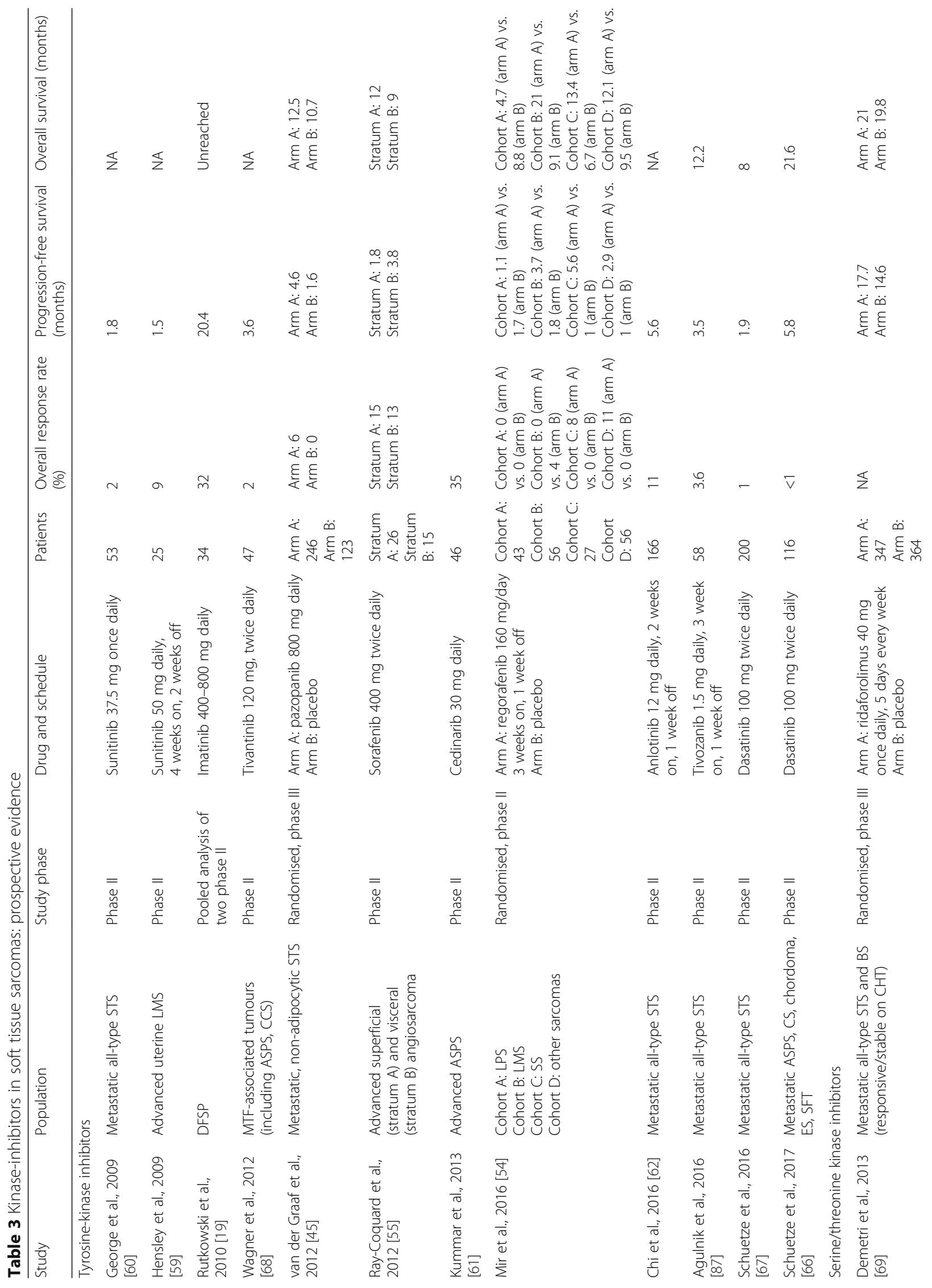




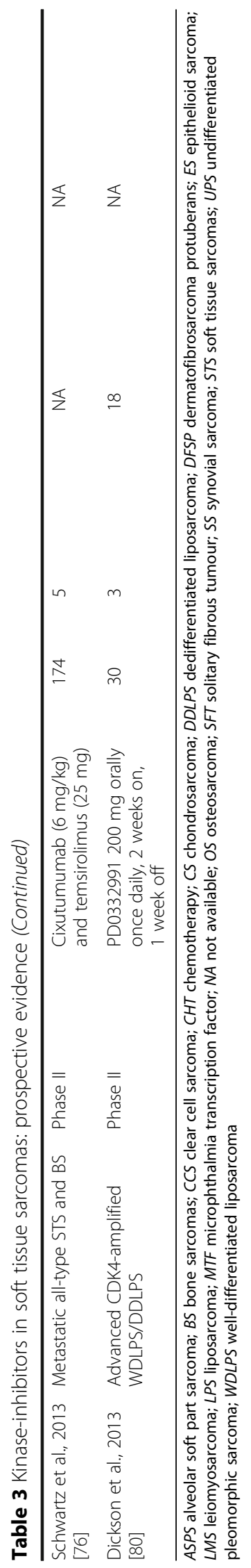


(NCT01524926). Tivantinib, a selective MET inhibitor, was also tested in a phase 2 study including ASPS and clear cell sarcoma, but only a modest activity was reported [68].

\section{Serine/threonine kinase inhibitors}

The better comprehension of STS biology led to the identification of several biological mechanisms potentially applicable in new drug development. The value of mammalian target of rapamycin (mTOR) inhibition in STS has been extensively exploited. With the view of prolonging the duration of disease control in patients who achieved a previous stabilisation or response to chemotherapy, the phase 3 SUCCEED trial tested the possible role of ridaforolimus, a serine/threonine kinase inhibitor targeting mTOR, as a maintenance therapy [69]. The study showed only a modest benefit in PFS for the drug compared to placebo (17.7 vs. 14.6 weeks, $P=0.001$ ), according to which this approach cannot be recommended in this setting. Across histologies, mTORinhibition is known to be active in PEComas, often harbouring genetic aberrations and activation of the TSC1/2-mTOR signalling pathway. The use of sirolimus and temsirolimus in this subtype induces consistent but often short-lasting responses [70-72]. Sirolimus has shown activity in epithelioid hemangioendothelioma, with a reported clinical benefit rate of 56\% [73]. Conflicting results have been described for STS of all types on the association between mTOR and IGF1R inhibitors, with more convincing evidence for Ewing sarcoma [74-76]. A possible role for mTOR inhibition in neurofibromatosis type 1-related malignant peripheral nerve sheath tumour (MPNST) has also been postulated [77]. The inhibition of MAPK signalling through salumetinib, an oral selective inhibitor of MAPK kinase 1 and 2, has led to encouraging results in paediatric neurofibromatosis type 1 patients with inoperable plexiform neurofibromas, providing a rationale for its investigation in MPNST [78]. Among serine/threonine kinases, the role of CDK4 has been studied in STS, highlighting an overexpression of the protein in more than $90 \%$ of well-differentiated/dedifferentiated liposarcoma (WDLS/DDLS) [79]. The phosphorylation of the retinoblastoma protein allowed by cyclin $\mathrm{D} / \mathrm{CDK} 4 / 6$ causes the detachment of retinoblastoma protein from the E2F transcription factor, leading to the transcription of multiple target genes including MDM2. The activity of palbociclib, a CDK4/CDK6-inhibitor currently approved in breast cancer, in CDK4-positive WDLS/DDLS was shown in a phase 2 study reporting a 12-week PFS rate of $66 \%$ [80]. A second phase 2 study (NCT01209598) testing different doses and schedules to minimise haematological toxicity has recently completed accrual and results are awaited.

\section{Small molecule inhibitors}

As for other small molecule inhibitors, the role of MDM2-antagonists and histone deacetylase inhibitors is currently under investigation. In a proof-of-mechanism study from a French group [81], 20 patients with chemotherapy-naïve primary or relapsed WDLS/DDLS, MDM2 amplified and eligible for resection, received RG7112, a MDM2-antagonist, with one response and 14 stable disease cases being reported, albeit with a significant gastrointestinal and bone-marrow toxicity. A phase $1 \mathrm{~b} / 2$ study (NCT01605526) is currently evaluating the tolerability and activity of a potentially less toxic compound, RO5045337, in association with doxorubicin. An intriguing new therapeutic approach that is currently under development in STS is represented by the inhibition of histone methylation, resulting in chromatin remodelling and modulation of the resultant transcriptional output. Tazemetostat is a small molecule inhibitor of the histone-lysine methyltransferase EZH2, whose activity is enhanced in integrase interactor 1 (INI1)-deficient tumours [82]. Among STS, genetic loss of INI1 has been reported in epithelioid MPNST, extraskeletal myxoid chondrosarcoma, myoepithelial carcinoma and up to $90 \%$ of epithelioid sarcoma [83-85]. INI1 can be deficient in synovial sarcoma (SS) marked by the fusion genes SS18SSX1. The resulting fusion protein causes the displacement of wild-type SS18 and INI1 from the SWI/SNF complex, leading to INI1 proteolytic degradation [86]. Given the preliminary results of the phase $1 / 2$ study showing activity of tazemetostat in INI1 deficient tumours (NCT02601950) [87], a phase 2 trial (NCT02601950) is currently ongoing to assess the activity of the drug in this group of solid cancers, including INI1-deficient epithelioid sarcoma and SS marked by the SS18-SSX1 translocation.

\section{Immunotherapy}

Immunotherapy has been one of the major breakthroughs in oncology, for both solid and haematological tumours. Despite historical evidence supporting its role in STS, the results currently reported with adoptive immunotherapy and immune synapse blockade remain controversial. NY-ESO-1, a member of the cancer testis family of tumour antigens, is expressed in approximately $80 \%$ of SS cases. A multi-cohort pilot study (NCT01343043) is currently testing the activity of genetically engineered NYESO-1c259 SPEAR T-cells in HLA-A*02 patients with SS undergoing different lymphodepleting regimens. The preliminary results show a reasonable tolerability and support the activity of the approach in this histology, with responses described independently from the level of NYESO-1 expression. The absence of objective responses in the cohort not receiving fludarabine within the preparative regimen let the authors postulate a role for the drug in the induction of response [88]. The activity of pembrolizumab 
Table 4 Immunotherapy in soft tissue sarcomas

\begin{tabular}{|c|c|c|c|c|c|}
\hline Study & Population & Study phase, status & Drug and schedule & Patients & $\begin{array}{l}\text { Overall response } \\
\text { rate (\%) }\end{array}$ \\
\hline $\begin{array}{l}\text { Mackall et al., } \\
2016 \text { [88] }\end{array}$ & Synovial sarcoma & $I / I I$, recruiting & $\begin{array}{l}\text { NY-ESO-1c259 SPEAR T-cells } \\
\text { Cohort } 1 \text { and 2: FL } 30 \mathrm{mg} / \mathrm{m}^{2} / \text { day, } \\
\text { day 1-4; CTX } 1800 \mathrm{mg} / \mathrm{m}^{2} / \text { day day } 1-2 \\
\text { Cohort 3: CTX } 1800 \mathrm{mg} / \mathrm{m}^{2} / \text { day day } 1-2 \\
\text { Cohort 4: FL } 30 \mathrm{mg} / \mathrm{m}^{2} / \text { day, day } 1-3 ; \\
\text { CTX } 600 \mathrm{mg} / \mathrm{m}^{2} / \text { day; day } 1-3\end{array}$ & $\begin{array}{l}\text { Cohort 1: } 15 \\
\text { Cohort 2: } 2 \\
\text { Cohort 3: } 2 \\
\text { Cohort 4: } 0\end{array}$ & $\begin{array}{l}\text { Cohort 1: } 50 \\
\text { Cohort 2: NA } \\
\text { Cohort 3: NA } \\
\text { Cohort 4: NA }\end{array}$ \\
\hline $\begin{array}{l}\text { Italiano et al., } \\
2016 \text { [90] }\end{array}$ & $\begin{array}{l}\text { LMS (Arm A), UPS } \\
\text { (Arm B), GIST (Arm C), } \\
\text { OS (Arm D), other } \\
\text { sarcomas (Arm E) }\end{array}$ & $\|$, recruiting in arm $B$ and $D$ & $\begin{array}{l}\text { Pembrolizumab } 200 \mathrm{mg} \text { i.v. 3-weekly; } \\
\text { CTX } 50 \text { mg BID } 1 \text { week on, } 1 \text { week off }\end{array}$ & $\begin{array}{l}\text { Arm A: } 15 \\
\text { Arm B: } 0 \\
\text { Arm C: } 10 \\
\text { Arm D: } 0 \\
\text { Arm E: } 16\end{array}$ & No objective responses \\
\hline $\begin{array}{l}\text { Burgess et al., } \\
2016 \text { [89] }\end{array}$ & $\begin{array}{l}\text { All-type STS (arm A) } \\
\text { and BS (arm B) }\end{array}$ & II, completed & Pembrolizumab, 200mg i.v., 3-weekly & $\begin{array}{l}\text { Arm A: } 40 \\
\text { Arm B: } 40\end{array}$ & $\begin{array}{l}\text { Arm A: } 17.5 \\
\text { (UPS, LPS, SS) } \\
\text { Arm B: } 5 \text { (OS, CS) }\end{array}$ \\
\hline $\begin{array}{l}\text { Paoluzzi et al., } \\
2016 \text { [91] }\end{array}$ & All-type STS and BS & Retrospective & $\begin{array}{l}\text { Arm A: nivolumab } 3 \text { mg/kg i.v., } \\
\text { 2-weekly } \\
\text { Arm B: nivolumab } 3 \text { mg/kg i.v., } \\
\text { 2-weekly + pazopanib } 800 \text { mg/day }\end{array}$ & $\begin{array}{l}\text { Arm A: } 10 \\
\text { Arm B: } 18\end{array}$ & $\begin{array}{l}\text { Arm A: } 10 \text { (CS) } \\
\text { Arm B: } 11 \text { (ES, OS) }\end{array}$ \\
\hline $\begin{array}{l}\text { George et al., } \\
2016 \text { [90] }\end{array}$ & Leiomyosarcoma & $\|$ & Nivolumab 3 mg/kg i.v., 2-weekly & 12 & No objective resp \\
\hline
\end{tabular}
2016 [90]

BS bone sarcomas; CS chondrosarcoma; CTX cyclophosphamide; ES epithelioid sarcoma; FL fludarabine; GIST Gastrointestinal stromal tumors; LMS leiomyosarcoma; LPS liposarcoma; NA not available; OS osteosarcoma; SS synovial sarcoma; STS soft tissue sarcomas; UPS undifferentiated pleomorphic sarcoma

and nivolumab, 2 humanised monoclonal IgG4 antibodies directed against the cell surface receptor PD-1, has also been preliminarily explored, both alone or in combination with cytotoxic and antiangiogenic drugs. In the SARC028 phase 2 study [89], pembrolizumab as a single agents showed activity in unselected STS of all types, with an ORR of $17.5 \%$ and a $55 \%$ 3-month PFS; undifferentiated pleomorphic sarcoma and DDLS were the histologies that seemed to benefit the most. In the French experience with the same compound [90], one response was reported in a SFT, treated in combination with cyclophosphamide. In a phase 2 study evaluating the activity of nivolumab alone or in association with pazopanib [91], one response in an epithelioid sarcoma patient was recorded in the group treated with the combination, but no signs of activity in STS for the drug as a single agent were reported. Despite an anecdotal response reported, nivolumab as a single agent failed to demonstrate antitumor activity in a phase 2 study on 12 patients with advanced uterine leiomyosarcoma [92, 93]. Nevertheless, the value of immunotherapy in STS is still largely unexplored. Further research is on-going to allow better patient selection and to investigate new combinatorial strategies. Results from the available studies on immunotherapy in STS are summarised in Table 4.

\section{Conclusions}

Doxorubicin remains to date the standard in the treatment of advanced STS. The combination with ifosfamide should be considered upfront in fit patients who might benefit from tumour response and in histologies with selective sensitivity to alkylating agents. Despite encouraging preliminary data, results from the recently completed phase 3 study on olaratumab and doxorubicin are required to confirm the value of this combination in first-line treatment. Beyond the first line, the treatment for STS is being increasingly driven by histology. Newer strategies, including drugs targeting epigenetic mechanisms and immunotherapies, are currently being developed to improve the outcome in this population.

\section{Funding \\ No funding for this manuscript.}

Authors' contributions

All authors contributed equally to this work.

\section{Competing interests}

AMF has no conflict of interest to disclose. SS received compensation for Advisory Boards from Plexxicon, Bayer, Karyopharm, and Lilly; research funds from Plexxicon, Pfizer, Glaxo, Bayer, Amgen, Novartis, Pharmamar, Infinity Pharmaceuticals, Morphotek, ImClone, Lilly, and Epyzime; and travel coverage from Pharmamar. AG received honoraria and compensation for Advisory Boards from Novartis, Bayer, Pfizer, Lilly, and Amgen; and honoraria and travel coverage from Pharmamar.

\section{Publisher's Note}

Springer Nature remains neutral with regard to jurisdictional claims in published maps and institutional affiliations.

\section{Author details}

${ }^{1}$ Department of Cancer Medicine, Fondazione IRCCS Istituto Nazionale dei Tumori, Milan, Italy. ${ }^{2}$ Department of Surgery, Fondazione IRCCS Istituto Nazionale dei Tumori, Via Venezian 1, Milan 20133, Italy.

Received: 27 February 2017 Accepted: 15 May 2017

Published online: 02 June 2017

\section{References}

1. Fletcher CD, Hogendoorn PC, Mertens F, Bridge J. WHO Classification of Tumours of Soft Tissue and Bone. 4th ed. Lyon: IARC press; 2013. 
2. Judson I, Verweij J, Gelderblom H, Hartmann JT, Schoffski P, Blay JY, Kerst JM, Sufliarsky J, Whelan J, Hohenberger $P$, et al. Doxorubicin alone versus intensified doxorubicin plus ifosfamide for first-line treatment of advanced or metastatic soft-tissue sarcoma: a randomised controlled phase 3 trial. Lancet Oncol. 2014;15:415-23.

3. Ryan CW, Merimsky O, Agulnik M, Blay JY, Schuetze SM, Van Tine BA, Jones RL, Elias AD, Choy E, Alcindor T, et al. PICASSO III: A phase III, placebocontrolled study of doxorubicin with or without palifosfamide in patients with metastatic soft tissue sarcoma. J Clin Oncol. 2016;34:3898-3905.

4. Tap WD, Jones RL, Van Tine BA, Chmielowski B, Elias AD, Adkins D, Agulnik M, Cooney MM, Livingston MB, Pennock G, et al. Olaratumab and doxorubicin versus doxorubicin alone for treatment of soft-tissue sarcoma: an open-label phase $1 \mathrm{~b}$ and randomised phase 2 trial. Lancet. 2016:388:488-97.

5. Lorigan P, Verweij J, Papai Z, Rodenhuis S, Le Cesne A, Leahy MG, Radford JA, Van Glabbeke MM, Kirkpatrick A, Hogendoorn PC, et al. Phase III trial of two investigational schedules of ifosfamide compared with standard-dose doxorubicin in advanced or metastatic soft tissue sarcoma: a European Organisation for Research and Treatment of Cancer Soft Tissue and Bone Sarcoma Group Study. J Clin Oncol. 2007;25:3144-50.

6. Chawla SP, Papai Z, Mukhametshina G, Sankhala K, Vasylyev L, Fedenko A, Khamly K, Ganjoo K, Nagarkar R, Wieland S, Levitt DJ. First-line aldoxorubicin vs doxorubicin in metastatic or locally advanced unresectable soft-tissue sarcoma: a phase 2b randomized clinical trial. JAMA Oncol. 2015;1:1272-80.

7. Salvatorelli E, Menna P, Gonzalez Paz O, Surapaneni S, Aukerman SL, Chello M, Covino E, Sung V, Minotti G. Pharmacokinetic characterization of amrubicin cardiac safety in an ex vivo human myocardial strip model. II. Amrubicin shows metabolic advantages over doxorubicin and epirubicin. J Pharmacol Exper Ther. 2012;341:474-83.

8. Noguchi T, Ichii S, Morisada S, Yamaoka T, Yanagi Y. Tumor-selective distribution of an active metabolite of the 9-aminoanthracycline amrubicin. Jpn J Cancer Res. 1998:89:1061-6.

9. Gupta S, Gouw L, Wright J, Chawla S, Pitt D, Wade M, Boucher K, Sharma S. Phase II study of amrubicin (SM-5887), a synthetic 9-aminoanthracycline, as first line treatment in patients with metastatic or unresectable soft tissue sarcoma: durable response in myxoid liposarcoma with TLS-CHOP translocation. Invest New Drugs. 2016;34:243-52.

10. Verschraegen CF, Chawla SP, Mita MM, Ryan CW, Blakely L, Keedy VL, Santoro A, Buck JY, Maki RG, Lewis JJ, PICASSO Study Investigators. A phase II, randomized, controlled trial of palifosfamide plus doxorubicin versus doxorubicin in patients with soft tissue sarcoma (PICASSO). J Clin Oncol. 2010;28:15s. Suppl; abstr 10004

11. Tap W, Papai Z, van Tine B, Attia S, Ganjoo K, Jones RL, Schuetze S, Reed D, Chawla SP, Riedel R, Krarup-Hansen A, Italiano A, Hohenberger P, Grignani G, Cranmer L, Alcindor T, Lopez-Pousa A, Pearce T, Kroll S, Schoffski P. Randomized phase 3, multicenter, open-label study comparing evofosfamide (Evo) in combination with doxorubicin (D) vs. D alone in patients (pts) with advanced soft tissue sarcoma (STS): Study TH-CR-406/ SARC021. Ann Oncol. 2016;27(Suppl_6):13950.

12. Seddon B, Whelan J, Strauss S, Leahy M, Woll P, Cowie F, Rothermundt C, Wood Z, Forsyth S, Khan I, et al. GeDDiS: A prospective randomised controlled phase III trial of gemcitabine and docetaxel compared with doxorubicin as first-line treatment in previously untreated advanced unresectable or metastatic soft tissue sarcomas (EudraCT 2009-014907-29). J Clin Oncol. 2015:33:(Suppl; abstr 10500).

13. Bui-Nguyen B, Butrynski JE, Penel N, Blay JY, Isambert N, Milhem M, Kerst JM, Reyners AK, Litiere S, Marreaud S, et al. A phase Ilb multicentre study comparing the efficacy of trabectedin to doxorubicin in patients with advanced or metastatic untreated soft tissue sarcoma: the TRUSTS trial. Eur J Cancer. 2015;51:1312-20.

14. Martin-Broto J, Pousa AL, de Las PR, Garcia Del Muro X, Gutierrez A, Martinez-Trufero J, Cruz J, Alvarez R, Cubedo R, Redondo A, et al. Randomized phase II study of trabectedin and doxorubicin compared with doxorubicin alone as first-line treatment in patients with advanced soft tissue sarcomas: a Spanish group for research on sarcoma study. J Clin Oncol. 2016;34:2294-302.

15. Gelderblom H, Blay JY, Seddon BM, Leahy M, Ray-Coquard I, Sleijfer S, Kerst JM, Rutkowski P, Bauer S, Ouali M, et al. Brostallicin versus doxorubicin as first-line chemotherapy in patients with advanced or metastatic soft tissue sarcoma: an European Organisation for Research and Treatment of Cancer Soft Tissue and Bone Sarcoma Group randomised phase II and pharmacogenetic study. Eur J Cancer. 2014;50:388-96.
16. Loizos N, Xu Y, Huber J, Liu M, Lu D, Finnerty B, Rolser R, Malikzay A, Persaud A, Corcoran E, et al. Targeting the platelet-derived growth factor receptor alpha with a neutralizing human monoclonal antibody inhibits the growth of tumor xenografts: implications as a potential therapeutic target. Mol Cancer Ther. 2005;4:369-79.

17. Simon MP, Pedeutour F, Sirvent N, Grosgeorge J, Minoletti F, Coindre JM, Terrier-Lacombe MJ, Mandahl N, Craver RD, Blin N, et al. Deregulation of the platelet-derived growth factor B-chain gene via fusion with collagen gene COL1A1 in dermatofibrosarcoma protuberans and giant-cell fibroblastoma. Nat Genet. 1997;15:95-8.

18. Greco A, Fusetti L, Villa R, Sozzi G, Minoletti F, Mauri P, Pierotti MA. Transforming activity of the chimeric sequence formed by the fusion of collagen gene COL1A1 and the platelet derived growth factor b-chain gene in dermatofibrosarcoma protuberans. Oncogene. 1998;17:1313-9.

19. Rutkowski P, Van Glabbeke M, Rankin CJ, Ruka W, Rubin BP, Debiec-Rychter M, Lazar A, Gelderblom H, Sciot R, Lopez-Terrada D, et al. Imatinib mesylate in advanced dermatofibrosarcoma protuberans: pooled analysis of two phase II clinical trials. J Clin Oncol. 2010;28:1772-9.

20. Stacchiotti S, Pantaleo MA, Negri T, Astolfi A, Tazzari M, Dagrada GP, Urbini M, Indio V, Maestro R, Gronchi A, et al. Efficacy and biological activity of imatinib in metastatic dermatofibrosarcoma protuberans (DFSP). Clin Cancer Res. 2016;22:837-46.

21. Reichardt $P$, Lindner T, Pink D, Thuss-Patience PC, Kretzschmar A, Dorken B. Chemotherapy in alveolar soft part sarcomas. What do we know? Eur J Cancer. 2003;39:1511-6.

22. Stacchiotti S, Libertini M, Negri T, Palassini E, Gronchi A, Fatigoni S, Poletti $P$ Vincenzi B, Dei Tos AP, Mariani $L$, et al. Response to chemotherapy of solitary fibrous tumour: a retrospective study. Eur J Cancer. 2013:49:2376-83.

23. Stacchiotti S, Palassini E, Sanfilippo R, Vincenzi B, Arena MG, Bochicchio AM, De Rosa P, Nuzzo A, Turano S, Morosi C, et al. Gemcitabine in advanced angiosarcoma: a retrospective case series analysis from the Italian Rare Cancer Network. Ann Oncol. 2012;23:501-8.

24. Duffaud F, Pautier P, Bui B, Hensley ML, Rey A, Penel N, Reinke D, Le Cesne A, Blay JY, Maki RG. A pooled analysis of the final results of the two randomized phase II studies comparing Gemcitabine $(G)$ vs Gemcitabine + Docetaxel $(G+D)$ in patients (pts) with metastatic/relapsed leiomyosarcoma (LMS). Milan: European Society for Medical Oncology; 2010.

25. Maki RG, Wathen JK, Patel SR, Priebat DA, Okuno SH, Samuels B, Fanucchi M, Harmon DC, Schuetze SM, Reinke D, et al. Randomized phase II study of gemcitabine and docetaxel compared with gemcitabine alone in patients with metastatic soft tissue sarcomas: results of sarcoma alliance for research through collaboration study 002 [corrected]. J Clin Oncol. 2007;25:2755-63.

26. Dileo P, Morgan JA, Zahrieh D, Desai J, Salesi JM, Harmon DC, Quigley MT, Polson K, Demetri GD, George S. Gemcitabine and vinorelbine combination chemotherapy for patients with advanced soft tissue sarcomas: results of a phase II trial. Cancer. 2007;109:1863-9.

27. Garcia-Del-Muro X, Lopez-Pousa A, Maurel J, Martin J, Martinez-Trufero J, Casado A, Gomez-Espana A, Fra J, Cruz J, Poveda A, et al. Randomized phase II study comparing gemcitabine plus dacarbazine versus dacarbazine alone in patients with previously treated soft tissue sarcoma: a Spanish Group for Research on Sarcomas study. J Clin Oncol. 2011;29:2528-33.

28. Stiles JM, Amaya C, Rains S, Diaz D, Pham R, Battiste J, Modiano JF, Kokta V, Boucheron LE, Mitchell DC, Bryan BA. Targeting of beta adrenergic receptors results in therapeutic efficacy against models of hemangioendothelioma and angiosarcoma. PLoS One. 2013;8, e60021.

29. Banavali S, Pasquier E, Andre N. Targeted therapy with propranolol and metronomic chemotherapy combination: sustained complete response of a relapsing metastatic angiosarcoma. Ecancermedicalscience. 2015;9:499.

30. Chow W, Amaya CN, Rains S, Chow M, Dickerson EB, Bryan BA. Growth attenuation of cutaneous angiosarcoma with propranolol-mediated betablockade. JAMA Dermatol. 2015;151:1226-9.

31. Penel N, Bui BN, Bay JO, Cupissol D, Ray-Coquard I, Piperno-Neumann S, Kerbrat P, Fournier C, Taieb S, Jimenez M, et al. Phase II trial of weekly paclitaxel for unresectable angiosarcoma: the ANGIOTAX Study. J Clinical Oncol. 2008;26:5269-74.

32. Rosen G, Forscher C, Lowenbraun S, Eilber F, Eckardt J, Holmes C, Fu YS. Synovial sarcoma. Uniform response of metastases to high dose ifosfamide. Cancer. 1994;73:2506-11.

33. Spurrell EL, Fisher C, Thomas JM, Judson IR. Prognostic factors in advanced synovial sarcoma: an analysis of 104 patients treated at the Royal Marsden Hospital. Ann Oncol. 2005;16:437-44. 
34. Le Cesne A, Blay JY, Judson I, Van Oosterom A, Verweij J, Radford J, Lorigan P, Rodenhuis S, Ray-Coquard I, Bonvalot S, et al. Phase II study of ET-743 in advanced soft tissue sarcomas: a European Organisation for the Research and Treatment of Cancer (EORTC) soft tissue and bone sarcoma group trial. J Clin Oncol. 2005;23:576-84.

35. Demetri GD, Chawla SP, von Mehren M, Ritch P, Baker LH, Blay JY, Hande KR, Keohan ML, Samuels BL, Schuetze S, et al. Efficacy and safety of trabectedin in patients with advanced or metastatic liposarcoma or leiomyosarcoma after failure of prior anthracyclines and ifosfamide: results of a randomized phase II study of two different schedules. J Clin Oncol. 2009;27:4188-96.

36. Forni C, Minuzzo M, Virdis E, Tamborini E, Simone M, Tavecchio M, Erba E, Grosso F, Gronchi A, Aman P, et al. Trabectedin (ET-743) promotes differentiation in myxoid liposarcoma tumors. Molec Cancer Therapeut. 2009;8:449-57.

37. Grosso F, Jones RL, Demetri GD, Judson IR, Blay JY, Le Cesne A, Sanfilippo R, Casieri P, Collini P, Dileo P, et al. Efficacy of trabectedin (ecteinascidin-743) in advanced pretreated myxoid liposarcomas: a retrospective study. Lancet Oncol. 2007;8:595-602.

38. Dybdal-Hargreaves NF, Risinger AL, Mooberry SL. Eribulin mesylate: mechanism of action of a unique microtubule-targeting agent. Clin Cancer Res. 2015;21:2445-52.

39. Yoshida T, Ozawa Y, Kimura T, Sato Y, Kuznetsov G, Xu S, Uesugi M, Agoulnik S, Taylor N, Funahashi Y, Matsui J. Eribulin mesilate suppresses experimental metastasis of breast cancer cells by reversing phenotype from epithelial-mesenchymal transition (EMT) to mesenchymal-epithelial transition (MET) states. Br J Cancer. 2014;110:1497-505.

40. Schoffski P, Chawla S, Maki RG, Italiano A, Gelderblom H, Choy E, Grignani G, Camargo V, Bauer S, Rha SY, et al. Eribulin versus dacarbazine in previously treated patients with advanced liposarcoma or leiomyosarcoma: a randomised, open-label, multicentre, phase 3 trial. Lancet. 2016;387:1629-37.

41. Gronchi A, Miceli R, Colombo C, Collini P, Stacchiotti S, Olmi P, Mariani L, Bertulli R, Fiore M, Casali PG. Primary extremity soft tissue sarcomas: outcome improvement over time at a single institution. Ann Oncol. 2011:22:1675-81.

42. Italiano A, Mathoulin-Pelissier S, Cesne AL, Terrier P, Bonvalot S, Collin F, Michels JJ, Blay JY, Coindre JM, Bui B. Trends in survival for patients with metastatic soft-tissue sarcoma. Cancer. 2011;117:1049-54.

43. Savina M, Le Cesne A, Blay JY, Ray-Coquard I, Mir O, Toulmonde M, Cousin S, Terrier P, Ranchere-Vince D, Meeus P, Stoeckle E, Honoré C, Sargos P, Sunyach MP, Le Péchoux C, Giraud A, Bellera C, Le Loarer F, Italiano A. Patterns of care and outcomes of patients with METAstatic soft tissue SARComa ina real-life setting: the METASARC observational study. BMC Med. 2017:15:78. doi:10.1186/s12916-017-0831-7.

44. Blanke CD, Demetri GD, von Mehren M, Heinrich MC, Eisenberg B, Fletcher JA, Corless CL, Fletcher CD, Roberts PJ, Heinz D, et al. Long-term results from a randomized phase II trial of standard- versus higher-dose imatinib mesylate for patients with unresectable or metastatic gastrointestinal stromal tumors expressing KIT. J Clin Oncol. 2008;26:620-5.

45. van der Graaf WT, Blay JY, Chawla SP, Kim DW, Bui-Nguyen B, Casali PG, Schoffski P, Aglietta M, Staddon AP, Beppu Y, et al. Pazopanib for metastatic soft-tissue sarcoma (PALETTE): a randomised, double-blind, placebocontrolled phase 3 trial. Lancet. 2012;379:1879-86.

46. Sleijfer S, Ray-Coquard I, Papai Z, Le Cesne A, Scurr M, Schoffski P, Collin F, Pandite L, Marreaud S, De Brauwer A, et al. Pazopanib, a multikinase angiogenesis inhibitor, in patients with relapsed or refractory advanced soft tissue sarcoma: a phase II study from the European organisation for research and treatment of cancer-soft tissue and bone sarcoma group (EORTC study 62043). J Clin Oncol. 2009:27:3126-32.

47. Kollar A, Jones RL, Stacchiotti S, Gelderblom H, Guida M, Grignani G, Steeghs N, Safwat A, Katz D, Duffaud F, et al. Pazopanib in advanced vascular sarcomas: an EORTC Soft Tissue and Bone Sarcoma Group (STBSG) retrospective analysis. Acta Oncol. 2017;56:88-92.

48. Stacchiotti S, Tortoreto M, Baldi GG, Grignani G, Toss A, Badalamenti G, Cominetti D, Morosi C, Dei Tos AP, Festinese F, et al. Preclinical and clinical evidence of activity of pazopanib in solitary fibrous tumour. Eur J Cancer. 2014;50:3021-8.

49. Stacchiotti S, Mir O, Vincenzi B, Fedenko A, Maki R, Somaiah N, Brahmi M, Boye $K$, Hindi N, Paterczyk H, et al. Pazopanib (P) and trabectedin (T) in alveolar soft part sarcoma (ASPS). In: 2016 Connective Tissue Oncology Society Annual Meeting, Lisbon; 2016. p. 135. https://www.ctos.org/Portals/ 0/PDF/CTOS_2016_Program_Full.pdf.

50. Sarkissian S, Fruehauf J. Pazopanib and taxane combinations for metastatic or recurrent soft tissue sarcoma: A retrospective case series. J Clin Oncol. 2016:34:(suppl; abstr e22528).
51. Schmoll H, Rüssel J, Reichardt P, Lindner L, Kopp H, Stein A, Cygon F, Heissner K. Pazopanib vs pazopanib + gemcitabine in refractory soft tissue sarcoma: A randomized phase II trial of the AIO. J Clin Oncol. 2016;34:(suppl; abstr 11004).

52. Attia S, Kumar Sankhala K, Riedel R, Robinson SCR, McKay Boland P, Barve MA, Fritchie K, Seon BK, Alvarez D, Adams BJ, Shazer R, Theuer C, Maki R. A phase 1B/phase 2A study of TRC105 (Endoglin Antibody) in combination with pazopanib (P) in patients (pts) with advanced soft tissue sarcoma (STS). J Clin Oncol. 2016;34:(suppl; abstr 11016).

53. Katz D, Peretz T, Eleyan F, Azraq Y, Merimsky O. Pazopanib plus sirolimus following escape from pazopanib alone: An intriguing observation-A series of 8 metastatic STS patients. J Clin Oncol. 2016;34:(suppl; abstr e22538).

54. Mir O, Brodowicz T, Italiano A, Wallet J, Blay JY, Bertucci F, Chevreau C, PipernoNeumann S, Bompas E, Salas S, et al. Safety and efficacy of regorafenib in patients with advanced soft tissue sarcoma (REGOSARC): a randomised, double-blind, placebo-controlled, phase 2 trial. Lancet Oncol. 2016;17:1732-42.

55. Ray-Coquard I, Italiano A, Bompas E, Le Cesne A, Robin YM, Chevreau C, Bay JO, Bousquet G, Piperno-Neumann S, Isambert N, et al. Sorafenib for patients with advanced angiosarcoma: a phase II Trial from the French Sarcoma Group (GSF/GETO). Oncologist. 2012;17:260-6.

56. Hindi N, Pilotti S, Maestro R, Dei Tos A, Palassini E, Morosi C, Messina A, Provenzano S, Negri T, Fiore M, et al. Sunitinib malate in advanced alveolar soft part sarcoma (ASPS): A final update after the closure of the named use program. J Clin Oncol. 2015;33:(suppl; abstr 10562).

57. Provenzano S, Maestro R, Dagrada G, Collini P, Pantaleo M, Astolfi A, Negri T, Gronchi A, Colombo C, Morosi C, et al. Sunitinib (SM) in advanced extraskeletal myxoid chondrosarcoma (EMC): Updated analysis in 11 patients (pts). J Clin Oncol. 2016;34:(suppl; abstr 11059).

58. Stacchiotti S, Grosso F, Negri T, Palassini E, Morosi C, Pilotti S, Gronchi A, Casali PG. Tumor response to sunitinib malate observed in clear-cell sarcoma. Ann Oncol. 2010;21:1130-1.

59. Hensley ML, Sill MW, Scribner Jr DR, Brown J, Debernardo RL, Hartenbach EM, McCourt CK, Bosscher JR, Gehrig PA. Sunitinib malate in the treatment of recurrent or persistent uterine leiomyosarcoma: a Gynecologic Oncology Group phase II study. Gynecol Oncol. 2009;115:460-5.

60. George S, Merriam P, Maki RG, Van den Abbeele AD, Yap JT, Akhurst T, Harmon DC, Bhuchar G, O'Mara MM, D'Adamo DR, et al. Multicenter phase II trial of sunitinib in the treatment of nongastrointestinal stromal tumor sarcomas. J Clin Oncol. 2009;27:3154-60.

61. Kummar S, Allen D, Monks A, Polley EC, Hose CD, Ivy SP, Turkbey IB, Lawrence $S$, Kinders RJ, Choyke $P$, et al. Cediranib for metastatic alveolar soft part sarcoma. J Clin Oncol. 2013;31:2296-302.

62. Chi Y, Sun Y, Cai J, Yao Y, Hong X, Fang Z, Sun P, Wang G, Wu Q, Qu G, et al. Phase II study of anlotinib for treatment of advanced soft tissues sarcomas. 2016 ASCO Annual Meeting. J Clin Oncol. 2016;34:(suppl; abstr 11005).

63. Agulnik M, Costa RLB, Milhem M, et al. A phase II study of tivozanib in patients with metastatic and nonresectable soft-tissue sarcomas. Ann Oncol. 2017;28(1):121-7.

64. Fu Y, Kang H, Zhao H, Hu J, Zhang H, Li X, Du N, Huang Y. Sunitinib for patients with locally advanced or distantly metastatic dermatofibrosarcoma protuberans but resistant to imatinib. Int J Clin Exper Med. 2015;8:8288-94.

65. Kamar FG, Kairouz VF, Sabri AN. Dermatofibrosarcoma protuberans (DFSP) successfully treated with sorafenib: case report. Clin Sarcoma Res. 2013;3:5.

66. Schuetze SM, Bolejack V, Choy E, Ganjoo KN, Staddon AP, Chow WA, Tawbi HA, Samuels BL, Patel SR, von Mehren M, et al. Phase 2 study of dasatinib in patients with alveolar soft part sarcoma, chondrosarcoma, chordoma, epithelioid sarcoma, or solitary fibrous tumor. Cancer. 2017;123:90-7.

67. Schuetze SM, Wathen JK, Lucas DR, Choy E, Samuels BL, Staddon AP, Ganjoo KN, von Mehren M, Chow WA, Loeb DM, et al. SARC009: Phase 2 study of dasatinib in patients with previously treated, high-grade, advanced sarcoma. Cancer. 2016;122:868-74.

68. Wagner AJ, Goldberg JM, Dubois SG, Choy E, Rosen L, Pappo A, Geller J, Judson I, Hogg D, Senzer N, et al. Tivantinib (ARQ 197), a selective inhibitor of MET, in patients with microphthalmia transcription factor-associated tumors: results of a multicenter phase 2 trial. Cancer. 2012;118:5894-902.

69. Demetri GD, Chawla SP, Ray-Coquard I, Le Cesne A, Staddon AP, Milhem MM, Penel N, Riedel RF, Bui-Nguyen B, Cranmer LD, et al. Results of an international randomized phase III trial of the mammalian target of rapamycin inhibitor ridaforolimus versus placebo to control metastatic 
sarcomas in patients after benefit from prior chemotherapy. J Clin Oncol. 2013;31:2485-92.

70. Benson C, Vitfell-Rasmussen J, Maruzzo M, Fisher C, Tunariu N, Mitchell S, AlMuderis $\mathrm{O}$, Thway K, Larkin J, Judson I. A retrospective study of patients with malignant PEComa receiving treatment with sirolimus or temsirolimus: the Royal Marsden Hospital experience. Anticancer Res. 2014;34:3663-8.

71. Wagner A, Malinowska-Kolodziej I, Morgan JA, Qin W, Fletcher CD, Vena N, Ligon AH, Antonescu CR, Ramaiya NH, Demetri GD, et al. Clinical activity of mTOR inhibition with sirolimus in malignant perivascular epithelioid cell tumors: targeting the pathogenic activation of mTORC1 in tumors. J Clin Oncol. 2010;28:835-40.

72. Italiano A, Delcambre C, Hostein I, Cazeau AL, Marty M, Avril A, Coindre JM, Bui B. Treatment with the mTOR inhibitor temsirolimus in patients with malignant PEComa. Ann Oncol. 2010;21:1135-7.

73. Stacchiotti S, Provenzano S, Dagrada G, Negri T, Brich S, Basso U, Brunello A, Grosso F, Galli L, Palassini E, et al. Sirolimus in advanced epithelioid hemangioendothelioma: a retrospective case-series analysis from the Italian Rare Cancer Network database. Ann Surg Oncol. 2016;23:2735-44.

74. Quek R, Wang Q, Morgan JA, Shapiro Gl, Butrynski JE, Ramaiya N, Huftalen T, Jederlinic N, Manola J, Wagner AJ, et al. Combination mTOR and IGF-1R inhibition: phase I trial of everolimus and figitumumab in patients with advanced sarcomas and other solid tumors. Clin Cancer Res. 2011;17:871-9.

75. Wagner LM, Fouladi M, Ahmed A, Krailo MD, Weigel B, DuBois SG, Doyle LA, Chen $\mathrm{H}$, Blaney SM. Phase II study of cixutumumab in combination with temsirolimus in pediatric patients and young adults with recurrent or refractory sarcoma: a report from the Children's Oncology Group. Pediatric Blood Cancer. 2015;62:440-4.

76. Schwartz GK, Tap WD, Qin LX, Livingston MB, Undevia SD, Chmielowski B, Agulnik M, Schuetze SM, Reed DR, Okuno SH, et al. Cixutumumab and temsirolimus for patients with bone and soft-tissue sarcoma: a multicentre, open-label, phase 2 trial. Lancet Oncol. 2013;14:371-82.

77. Endo M, Yamamoto H, Setsu N, Kohashi K, Takahashi Y, Ishii T, lida K, Matsumoto Y, Hakozaki M, Aoki M, et al. Prognostic significance of AKT/ mTOR and MAPK pathways and antitumor effect of mTOR inhibitor in NF1related and sporadic malignant peripheral nerve sheath tumors. Clin Cancer Res. 2013;19:450-61.

78. Dombi E, Baldwin A, Marcus $\sqcup$, Fisher MJ, Weiss B, Kim A, Whitcomb P, Martin S, Aschbacher-Smith LE, Rizvi TA, et al. Activity of selumetinib in neurofibromatosis type 1-related plexiform neurofibromas. N Engl J Med. 2016;375:2550-60.

79. Binh MB, Sastre-Garau X, Guillou L, de Pinieux G, Terrier P, Lagace R, Aurias A, Hostein I, Coindre JM. MDM2 and CDK4 immunostainings are useful adjuncts in diagnosing well-differentiated and dedifferentiated liposarcoma subtypes: a comparative analysis of 559 soft tissue neoplasms with genetic data. Am J Surgical Pathol. 2005;29:1340-7.

80. Dickson MA, Tap WD, Keohan ML, D'Angelo SP, Gounder MM, Antonescu CR, Landa J, Qin LX, Rathbone DD, Condy MM, et al. Phase II trial of the CDK4 inhibitor PD0332991 in patients with advanced CDK4-amplified welldifferentiated or dedifferentiated liposarcoma. J Clin Oncol. 2013;31:2024-8.

81. Ray-Coquard I, Blay JY, Italiano A, Le Cesne A, Penel N, Zhi J, Heil F, Rueger $R$, Graves B, Ding M, et al. Effect of the MDM2 antagonist RG7112 on the P53 pathway in patients with MDM2-amplified, well-differentiated or dedifferentiated liposarcoma: an exploratory proof-of-mechanism study. Lancet Oncol. 2012;13:1133-40.

82. Wilson BG, Wang X, Shen X, McKenna ES, Lemieux ME, Cho YJ, Koellhoffer EC, Pomeroy SL, Orkin SH, Roberts CW. Epigenetic antagonism between polycomb and SWI/SNF complexes during oncogenic transformation. Cancer Cell. 2010;18:316-28.

83. Carter JM, O'Hara C, Dundas G, Gilchrist D, Collins MS, Eaton K, Judkins AR, Biegel JA, Folpe AL. Epithelioid malignant peripheral nerve sheath tumor arising in a schwannoma, in a patient with "neuroblastoma-like" schwannomatosis and a novel germline SMARCB1 mutation. Am J Surgical Pathol. 2012;36:154-60.

84. Hornick JL, Dal Cin P, Fletcher CD. Loss of INI1 expression is characteristic of both conventional and proximal-type epithelioid sarcoma. Am J Surgical Pathol. 2009:33:542-50

85. Kohashi K, Oda Y, Yamamoto H, Tamiya S, Oshiro Y, Izumi T, Taguchi T, Tsuneyoshi M. SMARCB1/INI1 protein expression in round cell soft tissue sarcomas associated with chromosomal translocations involving EWS: a special reference to SMARCB1/INI1 negative variant extraskeletal myxoid chondrosarcoma. Am J Surgical Pathol. 2008;32:1168-74.

86. Kadoch C, Crabtree GR. Reversible disruption of mSWI/SNF (BAF) complexes by the SS18-SSX oncogenic fusion in synovial sarcoma. Cell. 2013;153:71-85.
87. Agulnik M, Tannir NM, Pressey JG, et al. A phase II, multicenter study of the EZH2 inhibitor tazemetostat in adult subjects with INI1-negative tumors or relapsed/refractory synovial sarcoma. J Clin Oncol. 2016;34:(suppl; abstr TPS11071).

88. Mackall C, D'Angelo S, Grupp S, Glod J, Druta M, Chow W, Chagin K, Mehler M, Kari G, Trivedi T, et al. Open label non-randomized multi-cohort pilot study of genetically engineered NY-ESO-1 specific NY-ESO-1 c259 SPEAR TcellsTM in HLA-A*02+ patients with synovial sarcoma (NCT01343043). Ann Oncol. 2016;27(Suppl_6):1075P.

89. Tawbi HAH, Burgess M, Crowley J, Van Tine B, Hu J, Schuetze S, D'Angelo S, Attia S, Priebat D, Okuno S, Riedel R, et al. Safety and efficacy of PD-1 blockade using pembrolizumab in patients with advanced soft tissue (STS) and bone sarcomas (BS): Results of SARC028-A multicenter phase II study. J Clin Oncol. 2016;34;(suppl; abstr 11006).

90. Italiano A, Penel N, Chevreau C, Blay J, Le Cesne A, Bompas E, PipernoNeumann S, Cousin S, Ryckewaert T, Pulido M, et al. Combination of pembrolizumab and metronomic cyclophosphamide in patients with advanced sarcomas: a French Sarcoma Group study. In: 2016 Connective Tissue Oncology Society Annual Meeting, Lisbon, 9-12 November, 2016. p. 139. https://www.ctos.org/Portals/O/PDF/CTOS_2016_Program_Full.pdf.

91. Paoluzzi L, Cacavio A, Ghesani M, Karambelkar A, Rapkiewicz A, Weber J, Rosen G. Response to anti-PD1 therapy with nivolumab in metastatic sarcomas. Clin Sarcoma Res. 2016;6:24.

92. Heine A, Kristiansen G, Schild HH, Brossart P. Successful treatment of refractory leiomyosarcoma with the PD-1 inhibitor nivolumab. Ann Oncol. 2016;27:1813-4

93. George S, Barysauskas CM, Solomon S, Tahlil K, Malley R, Hohos M, Polson K, Loucks M, Wagner AJ, Merriam P, et al. Phase 2 study of nivolumab in metastatic leiomyosarcoma of the uterus. J Clin Oncol. 2016;34:(suppl; abstr 11007).

\section{Submit your next manuscript to BioMed Central and we will help you at every step:}

- We accept pre-submission inquiries

- Our selector tool helps you to find the most relevant journal

- We provide round the clock customer support

- Convenient online submission

- Thorough peer review

- Inclusion in PubMed and all major indexing services

- Maximum visibility for your research

Submit your manuscript at www.biomedcentral.com/submit
( Biomed Central 